\title{
Effect of Drip Fertigation Levels on Fruit Quality Characters of Aonla (Emblica officinalis Gaertn.) cv. NA-7
}

\author{
P.M. Suresh ${ }^{1 *}$, S. Kumar ${ }^{2}$, V. Swaminathan ${ }^{3}$, A. Gurusamy ${ }^{4}$ and T. Shivakumar ${ }^{5}$ \\ ${ }^{1}$ School of Agricultural Sciences, Kalasalingam Academy of Research and Education, \\ Krishnankoil - 626 126, India \\ ${ }^{2}$ (Horticulture) Anbil Dharmalingam Agricultural College and Research Institute, Tamil Nadu \\ Agricultural University, Tiruchirappalli, India \\ ${ }^{3}$ (Horticulture) Horticultural College and Research Institute, Tamil Nadu Agricultural \\ University, Periyakulam - 625 604, India \\ ${ }^{4}$ Department of Agronomy, Agricultural College and Research Institute, Tamil Nadu \\ Agricultural University, Madurai - 625 104, India \\ ${ }^{5}$ Department of Crop Physiology, Tamil Nadu Agricultural University, \\ Coimbatore - 641 003, India \\ *Corresponding author
}

\section{A B S T R A C T}

\begin{tabular}{|l|}
\hline Key wor d s \\
Aonla, Drip \\
fertigation and fruit \\
characters
\end{tabular}

Investigations were undertaken to study the influence of drip fertigation levels on fruit quality characters in aonla was carried out during 2011 to 2013. The experiment was laid out in randomized block design with eight treatments of fertigation levels, namely 75,100 and $125 \%$ recommended dose of water soluble fertilizers including, soil application (control) and replicated three times, to test various fruit quality attributes of 8 years aonla cv. NA.7 grown under drip fertigation. The investigation indicated that $125 \%$ recommended dose of water soluble fertilizers $\left(\mathrm{T}_{8}\right)$ applied through fertigation resulted in maximum fruit quality characters viz., TSS $\left(13.1^{\circ}\right.$ Brix and $13.6^{\circ}$ Brix $)$, Acidity $(2.10 \%$ and $2.15 \%)$, Ascorbic acid (575.8mg gand 580.6mg g), Reducing sugar (2.70\% and 3.10 $\%)$, Non-Reducing sugar (1.60\% and $1.85 \%)$ and Total sugar (4.30\% and $4.95 \%)$ during 2011-2012 and 2012-2013 respectively. Therefore $\left(\mathrm{T}_{8}\right) 125 \%$ recommended doses of NPK in the form of water soluble fertilizers can be suggested for increasing the yield of eight years old aonla cv. NA.7 significantly.

\section{Introduction}

Aonla (Emblica officinalis L. Gaertn) is an important indigenous emerging fruit crop owing to its hardiness and ability to withstand adverse soil and climatic conditions and belongs to the family Euphorbiceae subfamily
Phyllanthoideae (Arun et al., 2009). It is originated in tropical South East Asia particularly South India (Virendra Singh et al., 2009). It is being cultivated since ancient times in India. The fruit is highly nutritive for human consumption. It is the richest source of vitamin C (600-1300 $\mathrm{mg} / 100 \mathrm{~g})$ among the 
fruits next to Barbados cherry and also useful for general improvement of health and medicinal purpose (Ram Kumar et al., 2011). Aonla is mainly cultivated in Mayanmar, Bangladesh, Sri Lanka Iran and Iraq. India ranks first in the world in aonla area and production. The area under aonla cultivation in India is about 77,000 hectares with an annual production 8, 26,000 tonnes (Anon, 2011). Since the natural ground water potential is diminishing, many farmers in India have opted drip irrigation. Through drip irrigation, fertigation is easier with high nutrient use efficiency, saving in labour, less weed infestation besides enhancing the productivity (Thiyagarajan, 2006).

Aonla responds to applied fertilizers to meet its nutrient requirements. Through fertigation methods, nutrients are added to the soil in adequate doses and interval through which qualitative improvement of produce can also be attained to a larger extent. Production of quality fruits in aonla will enable the farmers to earn more income. In Tamil Nadu, a dose of 200:500:200 $\mathrm{g} \mathrm{NPK}$ tree $^{-1}$ year $^{-1}$ is generally recommended (TNAU) for aonla.

This study was aimed to evaluate the fertigation system involving drip irrigation methods; various levels of fertilizers with a comparison on the farmers practice (surface irrigation + soil application of RDF) on leaf NPK and yield per tree of aonla

\section{Materials and Methods}

A field experiment was conducted at the Department of Horticulture, Agricultural College and Research Institute, Tamil Nadu Agricultural University, Madurai during the year 2011-12 and 2012-13. The research experiment conducted at College Model Orchard was aimed to standardize the fertigation schedule for aonla, to study the effect of fertigation with $\mathrm{N}, \mathrm{P}$ and $\mathrm{K}$ fertilizers on growth, yield and quality of aonla. The details of materials used $\mathrm{T}_{1-S}$ Surface Irrigation with soil application of $100 \%$ RDF (Control), $\mathrm{T}_{2}$-Drip Irrigation with soil application of 100 $\%$ RDF $\mathrm{T}_{3}$-Drip Fertigation of $75 \% \mathrm{RDF}$ as Commercial Fertilizers, $\mathrm{T}_{4}$-Drip Fertigation of $100 \%$ RDF as Commercial Fertilizers, $\mathrm{T}_{5-}$ Drip Fertigation of $125 \%$ RDF as Commercial Fertilizers $\mathrm{T}_{6}$-Drip Fertigation of $75 \% \mathrm{RDF}$ as Water Soluble Fertilizers (WSF), $\mathrm{T}_{7}$ Drip Fertigation of $100 \%$ RDF as Water Soluble Fertilizers (WSF) $\mathrm{T}_{8}$ - Drip Fertigation of $125 \%$ RDF as Water Soluble Fertilizers (WSF). All other recommended package of practices were followed to raise the crop as per the Crop Production Techniques of Horticultural Crops (2012).

For the treatment $T_{1}$-Soil application with surface irrigation was done in two split doses during April and September. For the treatment $\mathrm{T}_{2}$-Soil application with drip irrigation was done in two split doses during April and September. For drip fertigation treatments $\left(\mathrm{T}_{3^{-}}\right.$ $\mathrm{T}_{5}$ ) $\mathrm{P}$ was applied as basal through SSP, N and $\mathrm{K}$ were injected at weekly in equal splits. For drip fertigation treatments $\left(\mathrm{T}_{6}-\mathrm{T}_{8}\right)$ the WSF namely MAP, SOP and Urea were injected at weekly intervals in equal splits (52 weeks). RDF: 200:500:200 g NPK/tree/year.

\section{Results and Discussion}

\section{Effect of drip fertigation on quality parameters}

In any production system, the primary goal is to achieve the highest fruit yield per unit area with optimum fruit quality. In aonla, the quality is mainly judged by total soluble solids (TSS), total sugars, acidity and ascorbic acid content in fruits. Application of nutrients, either through soil (or) fertigation, has made a remarkable effect on fruit quality as observed by Syamal and Mishra (1988), Suriyapananant (1992) and Shah et al., (2002). 


\section{Total Soluble Solids}

The total soluble solid content was significantly differed among the treatments. This increased by application of 125 per cent RDF through fertigation (13.1 and $\left.13.6^{\circ} \mathrm{Brix}\right)$ followed by 100 per cent RDF through fertigation (12.6 and $13.2^{\circ}$ Brix) during 20112012 to $2012-2013$ respectively. The lowest total soluble solid content was recorded in control i.e. 6.5 and $7.0^{\circ}$ Brix in 2011-2012 to 2012 -2013 respectively.

Pooled Mean total soluble solid content was the highest due to 125 per cent RDF through fertigation $\left(\mathrm{T}_{8}\right) \quad\left(13.34{ }^{\circ} \mathrm{Brix}\right)$ and it was followed by 100 per cent RDF through fertigation $\left(\mathrm{T}_{7}\right)\left(12.90^{\circ}\right.$ Brix $)$. The lowest total soluble solid $\left(6.75^{\circ}\right.$ Brix) was recorded in control $\left(\mathrm{T}_{1}\right)$.The role of potassium in carbohydrate synthesis, breakdown and translocation, synthesis of protein and neutralization of physiologically important organic acids (Tistale and Nelson, 1966). Besides, potassium is involved in phloem loading and unloading of sucrose and amino acids and storage of sucrose in the form of starch in developing fruits by activating the enzyme 'starch synthase' (Mengel and Kirkby, 1987) (Table 1).

\section{Titrable acidity}

Titrable acidity was significantly influenced among the treatments and increased by application of 100 per cent RDF through soil application, i.e. control (3.20 and $3.50 \%)$. The lowest titrable acidity was recorded in treatments $\mathrm{T}_{8}(2.10$ and $2.15 \%)$ during 20112012 to $2012-2013$, respectively. It was followed by $\mathrm{T}_{7}$ i.e. (2.17 and $2.20 \%$ ) in 20112012 to $2012-2013$ respectively.

Similar trend was noticed in the pooled mean values also. The application of 100 per cent $\mathrm{RDF}$ through soil i.e. control recorded the highest titrable acidity $(3.35 \%)$. The lowest titrable acidity was recorded in treatments $\mathrm{T}_{8}$ followed by $\mathrm{T}_{7}(2.12$ and $2.18 \%)$ respectively. Increased level of potassium application results in reduced acid content of fruits. This could be due to the fact that under low potassium level, phosphoenol pyruvate (PEP) was apparently shunted into alternate pathways resulting in shortage of acetyl Co-A (Pattee and Teel, 1967). Hence, oxaloacetate appeared to be preferentially formed from PEP in plants with low levels of $\mathrm{K}$ and these organic acid derivatives accumulated Neutralization of organic acid due to high $\mathrm{K}$ level in tissues could have also resulted in reduction in acidity (Tistale and Nelson, 1966) (Table 2).

\section{Ascorbic acid content}

Ascorbic acid content of fruit was significantly different among the treatments and increased by application of 125 per cent RDF through fertigation $\left(\mathrm{T}_{8}\right)$ (575.8 and 580.6 $\mathrm{mg} \mathrm{g}^{-1}$ ). It was followed by $\mathrm{T}_{7}$, application of 100 per cent RDF through fertigation (540.3 and $560.3 \mathrm{mg} \mathrm{g}^{-1}$ ) during 2011-2012 to 2012 2013 respectively. The lowest ascorbic acid (335.6 and $350.4 \mathrm{mg} \mathrm{g}^{-1}$ ) content was recorded in treatment $T_{1}$ in 2011-2012 to $2012-2013$ respectively.

Similar trend was noticed in the pooled mean values also. The application of 125 per cent RDF through fertigation $\left(T_{8}\right)$ registered the highest ascorbic acid content (578.20 $\mathrm{mg} \mathrm{g}^{-1}$ ). It was followed by $\mathrm{T}_{7},\left(550.29 \mathrm{mg} \mathrm{g}^{-1}\right)$. The lowest ascorbic acid content (343.0 $\mathrm{mg} \mathrm{g}^{-1}$ ) was recorded in treatment 100 per cent RDF through soil $\left(\mathrm{T}_{1}\right)$ i.e. control $\left(\mathrm{T}_{1}\right)$. Potassium is responsible for energy production in the form of ATP and NADPH in chloroplasts by maintaining balanced electric charges. This high-energy status promotes synthesis of secondary metabolites like ascorbic acid (Mengel, 1997) (Table 3). 
Table.1 Effect of drip fertigation levels on TSS ( ${ }^{0}$ Brix) of aonla cv. NA-7

\begin{tabular}{|c|c|c|c|c|c|c|c|c|c|c|}
\hline \multicolumn{5}{|c|}{2012} & \multicolumn{5}{|c|}{2013} & \multirow{2}{*}{$\begin{array}{c}\text { Pooled mean } \\
2012-2013\end{array}$} \\
\hline Treatments & $\mathbf{R}_{1}$ & $\mathbf{R}_{2}$ & $\mathbf{R}_{3}$ & Mean & Treatments & $\mathbf{R}_{1}$ & $\mathbf{R}_{2}$ & $\mathbf{R}_{\mathbf{3}}$ & Mean & \\
\hline$T_{1}$ & 6.57 & 6.72 & 6.21 & 6.50 & $\mathrm{~T}_{1}$ & 7.26 & 6.65 & 7.09 & 7.00 & 6.75 \\
\hline$T_{2}$ & 8.47 & 8.62 & 8.11 & 8.40 & $\mathbf{T}_{2}$ & 9.88 & 9.53 & 9.39 & 9.60 & 9.00 \\
\hline$T_{3}$ & 9.39 & 9.16 & 9.96 & 9.50 & $\mathbf{T}_{3}$ & 10.22 & 10.21 & 10.17 & 10.2 & 9.85 \\
\hline$T_{4}$ & 9.44 & 10.28 & 9.68 & 9.80 & $\mathbf{T}_{4}$ & 11.70 & 11.45 & 11.35 & 11.5 & 10.65 \\
\hline$T_{5}$ & 11.50 & 11.49 & 11.51 & 11.5 & $\mathbf{T}_{5}$ & 12.37 & 12.39 & 12.44 & 12.4 & 11.95 \\
\hline$T_{6}$ & 9.92 & 9.17 & 9.71 & 9.60 & $T_{6}$ & 11.28 & 10.90 & 11.43 & 11.2 & 10.40 \\
\hline $\mathbf{T}_{7}$ & 12.57 & 12.64 & 12.59 & 12.6 & $\mathbf{T}_{7}$ & 13.03 & 13.24 & 13.33 & 13.2 & 12.90 \\
\hline $\mathrm{T}_{8}$ & 13.74 & 12.62 & 12.94 & 13.1 & $T_{8}$ & 13.76 & 13.65 & 13.38 & 13.6 & 13.34 \\
\hline \multicolumn{4}{|c|}{ SEd } & 0.287 & \multirow{2}{*}{\multicolumn{4}{|c|}{ SEd }} & 0.182 & 0.169 \\
\hline \multicolumn{4}{|c|}{$\mathrm{CD}(0.05)$} & 0.615 & & & & $\mathrm{CD}(0.05)$ & 0.390 & 0.348 \\
\hline
\end{tabular}

Table.2 Effect of drip fertigation levels on titrable acidity (\%) of aonla cv. NA-7

\begin{tabular}{|c|c|c|c|c|c|c|c|c|c|c|}
\hline \multicolumn{5}{|c|}{2012} & \multicolumn{5}{|c|}{2013} & \multirow{2}{*}{$\begin{array}{c}\text { Pooled mean } \\
\text { 2012-2013 }\end{array}$} \\
\hline Treatments & $\mathbf{R}_{1}$ & $\mathbf{R}_{2}$ & $\mathbf{R}_{\mathbf{3}}$ & Mean & Treatments & $\mathbf{R}_{1}$ & $\mathbf{R}_{2}$ & $\mathbf{R}_{\mathbf{3}}$ & Mean & \\
\hline $\mathrm{T}_{1}$ & 3.19 & 3.22 & 3.20 & 3.20 & $\mathrm{~T}_{1}$ & 3.50 & 3.50 & 3.50 & 3.50 & 3.35 \\
\hline $\mathbf{T}_{2}$ & 2.53 & 2.69 & 2.64 & 2.62 & $\mathbf{T}_{2}$ & 2.80 & 2.75 & 2.62 & 2.72 & 2.67 \\
\hline$T_{3}$ & 2.49 & 2.48 & 2.53 & 2.50 & $\mathbf{T}_{3}$ & 2.61 & 2.57 & 2.62 & 2.60 & 2.55 \\
\hline$T_{4}$ & 2.48 & 2.34 & 2.38 & 2.40 & $\mathbf{T}_{4}$ & 2.43 & 2.40 & 2.52 & 2.45 & 2.42 \\
\hline$T_{5}$ & 2.24 & 2.23 & 2.22 & 2.23 & $\mathbf{T}_{5}$ & 2.31 & 2.28 & 2.30 & 2.30 & 2.26 \\
\hline $\mathrm{T}_{6}$ & 2.52 & 2.46 & 2.43 & 2.47 & $T_{6}$ & 2.52 & 2.54 & 2.59 & 2.55 & 2.51 \\
\hline $\mathrm{T}_{7}$ & 2.18 & 2.21 & 2.12 & 2.17 & $\mathbf{T}_{7}$ & 2.20 & 2.20 & 2.20 & 2.20 & 2.18 \\
\hline $\mathrm{T}_{8}$ & 2.12 & 2.15 & 2.03 & 2.10 & $\mathbf{T}_{8}$ & 2.20 & 2.14 & 2.11 & 2.15 & 2.12 \\
\hline \multicolumn{4}{|c|}{ SEd } & 0.042 & \multicolumn{4}{|c|}{ SEd } & 0.038 & 0.028 \\
\hline \multicolumn{4}{|c|}{$\mathrm{CD}(0.05)$} & 0.091 & \multicolumn{4}{|c|}{$\mathrm{CD}(0.05)$} & 0.083 & 0.059 \\
\hline
\end{tabular}

Table.3 Effect of drip fertigation levels on ascorbic acid $\left(\mathrm{mg} \mathrm{g}^{-1}\right)$ of aonla cv. NA-7

\begin{tabular}{|c|c|c|c|}
\hline & \multicolumn{3}{|c|}{2012} \\
\hline Treatments & $\mathbf{R}_{1}$ & $\mathbf{R}_{\mathbf{2}}$ & $\mathbf{R}_{\mathbf{3}}$ \\
\hline $\mathrm{T}_{1}$ & 333.53 & 329.38 & 343.89 \\
\hline $\mathrm{T}_{2}$ & 434.24 & 425.69 & 422.27 \\
\hline $\mathrm{T}_{3}$ & 442.55 & 414.67 & 434.58 \\
\hline $\mathrm{T}_{4}$ & 440.50 & 440.50 & 440.50 \\
\hline $\mathrm{T}_{5}$ & 513.87 & 507.62 & 509.41 \\
\hline $\mathrm{T}_{6}$ & 444.26 & 439.31 & 437.33 \\
\hline $\mathrm{T}_{7}$ & 530.98 & 537.19 & 552.73 \\
\hline $\mathrm{T}_{8}$ & 577.24 & 580.12 & 570.04 \\
\hline \multicolumn{3}{|c|}{ SEd } \\
\hline
\end{tabular}

\begin{tabular}{|c|c|c|c|c|c|}
\hline \multicolumn{5}{|c|}{2013} & Pooled mean \\
\hline Treatments & $\mathbf{R}_{\mathbf{1}}$ & $\mathbf{R}_{\mathbf{2}}$ & $\mathbf{R}_{\mathbf{3}}$ & Mean & 2012-2013 \\
\hline $\mathbf{T}_{\mathbf{1}}$ & 332.95 & 354.76 & 363.49 & $\mathbf{3 5 0 . 4}$ & 343.00 \\
\hline $\mathbf{T}_{\mathbf{2}}$ & 452.84 & 430.54 & 421.62 & $\mathbf{4 3 5 . 0}$ & 431.20 \\
\hline $\mathbf{T}_{\mathbf{3}}$ & 432.53 & 440.18 & 437.99 & $\mathbf{4 3 6 . 9}$ & 433.75 \\
\hline $\mathbf{T}_{\mathbf{4}}$ & 441.53 & 449.37 & 452.50 & $\mathbf{4 4 7 . 8}$ & 444.15 \\
\hline $\mathbf{T}_{\mathbf{5}}$ & 541.10 & 508.20 & 517.60 & $\mathbf{5 2 2 . 3}$ & 516.30 \\
\hline $\mathbf{T}_{\mathbf{6}}$ & 437.75 & 454.99 & 450.06 & $\mathbf{4 4 7 . 6}$ & 443.95 \\
\hline $\mathbf{T}_{\mathbf{7}}$ & 555.40 & 545.59 & 579.91 & $\mathbf{5 6 0 . 3}$ & 550.29 \\
\hline $\mathbf{T}_{\mathbf{8}}$ & 576.97 & 569.71 & 595.12 & $\mathbf{5 8 0 . 6}$ & 578.20 \\
\hline & $\mathbf{S E d}$ & & $\mathbf{1 0 . 9 6 3}$ & $\mathbf{6 . 3 0 9}$ \\
\hline
\end{tabular}


Table.4 Effect of drip fertigation levels on total sugar (\%) of aonla cv. NA-7

\begin{tabular}{|c|c|c|c|c|c|c|c|c|c|c|}
\hline \multicolumn{5}{|c|}{2012} & \multicolumn{5}{|c|}{2013} & \multirow{2}{*}{$\begin{array}{c}\text { Pooled mean } \\
\text { 2012-2013 }\end{array}$} \\
\hline Treatments & $\mathbf{R}_{1}$ & $\mathbf{R}_{2}$ & $\mathbf{R}_{\mathbf{3}}$ & Mean & Treatments & $\mathbf{R}_{1}$ & $\mathbf{R}_{2}$ & $\mathbf{R}_{\mathbf{3}}$ & Mean & \\
\hline $\mathrm{T}_{1}$ & 2.31 & 2.28 & 2.21 & 2.27 & $T_{1}$ & 2.35 & 2.47 & 2.52 & 2.45 & 2.36 \\
\hline$T_{2}$ & 2.92 & 2.85 & 2.87 & 2.88 & $\mathbf{T}_{2}$ & 3.00 & 3.05 & 3.01 & 3.02 & 2.95 \\
\hline$\overline{T_{3}}$ & 3.12 & 2.98 & 3.08 & 3.06 & $\mathbf{T}_{\mathbf{3}}$ & 3.17 & 3.40 & 3.33 & 3.30 & 3.18 \\
\hline $\mathrm{T}_{4}$ & 3.35 & 3.38 & 3.47 & 3.40 & $\mathbf{T}_{4}$ & 3.76 & 3.85 & 3.55 & 3.72 & 3.56 \\
\hline $\mathbf{T}_{5}$ & 3.85 & 3.82 & 3.73 & 3.80 & $\mathbf{T}_{5}$ & 4.07 & 4.24 & 4.12 & 4.14 & 3.96 \\
\hline $\mathrm{T}_{6}$ & 3.12 & 3.08 & 3.11 & 3.10 & $\mathbf{T}_{6}$ & 3.49 & 3.20 & 3.41 & 3.37 & 3.23 \\
\hline$T_{7}$ & 3.96 & 3.98 & 3.91 & 3.95 & $\mathbf{T}_{7}$ & 4.56 & 4.45 & 4.40 & 4.47 & 4.20 \\
\hline $\mathrm{T}_{8}$ & 4.36 & 4.32 & 4.21 & 4.30 & $\mathbf{T}_{8}$ & 5.08 & 4.77 & 4.99 & 4.95 & 4.62 \\
\hline \multicolumn{4}{|c|}{ SEd } & 0.042 & \multicolumn{4}{|c|}{ SEd } & 0.101 & 0.054 \\
\hline \multicolumn{4}{|c|}{$\mathrm{CD}(0.05)$} & 0.092 & \multicolumn{4}{|c|}{$\mathrm{CD}(0.05)$} & 0.218 & 0.112 \\
\hline
\end{tabular}

Table.5 Effect of drip fertigation levels on reducing sugar (\%) of aonla cv. NA-7

\begin{tabular}{|c|c|c|c|c|c|c|c|c|c|c|}
\hline & \multicolumn{2}{|c|}{2012} & \multicolumn{9}{|c|}{2013} & Pooled mean \\
\hline Treatments & $\mathbf{R}_{\mathbf{1}}$ & $\mathbf{R}_{\mathbf{2}}$ & $\mathbf{R}_{\mathbf{3}}$ & Mean & Treatments & $\mathbf{R}_{\mathbf{1}}$ & $\mathbf{R}_{\mathbf{2}}$ & $\mathbf{R}_{\mathbf{3}}$ & Mean & 2012-2013 \\
\hline $\mathrm{T}_{\mathbf{1}}$ & 1.44 & 1.34 & 1.41 & $\mathbf{1 . 4 0}$ & $\mathbf{T}_{\mathbf{1}}$ & 1.54 & 1.51 & 1.44 & $\mathbf{1 . 5 0}$ & 1.45 \\
\hline $\mathrm{T}_{\mathbf{2}}$ & 1.82 & 1.86 & 1.72 & $\mathbf{1 . 8 0}$ & $\mathbf{T}_{\mathbf{2}}$ & 1.90 & 1.90 & 1.90 & $\mathbf{1 . 9 0}$ & 1.85 \\
\hline $\mathrm{T}_{\mathbf{3}}$ & 1.88 & 1.93 & 1.89 & $\mathbf{1 . 9 0}$ & $\mathbf{T}_{\mathbf{3}}$ & 2.11 & 2.13 & 2.06 & $\mathbf{2 . 1 0}$ & 2.00 \\
\hline $\mathrm{T}_{4}$ & 2.20 & 2.21 & 2.20 & $\mathbf{2 . 2 0}$ & $\mathbf{T}_{\mathbf{4}}$ & 2.23 & 2.39 & 2.28 & $\mathbf{2 . 3 0}$ & 2.25 \\
\hline $\mathrm{T}_{5}$ & 2.47 & 2.30 & 2.42 & $\mathbf{2 . 4 0}$ & $\mathbf{T}_{\mathbf{5}}$ & 2.61 & 2.47 & 2.42 & $\mathbf{2 . 5 0}$ & 2.45 \\
\hline $\mathrm{T}_{6}$ & 2.05 & 1.96 & 1.99 & $\mathbf{2 . 0 0}$ & $\mathbf{T}_{\mathbf{6}}$ & 2.28 & 2.09 & 2.23 & $\mathbf{2 . 2 0}$ & 2.10 \\
\hline $\mathrm{T}_{\mathbf{7}}$ & 2.50 & 2.52 & 2.49 & $\mathbf{2 . 5 0}$ & $\mathbf{T}_{\mathbf{7}}$ & 2.78 & 2.74 & 2.88 & $\mathbf{2 . 8 0}$ & 2.64 \\
\hline $\mathrm{T}_{\mathbf{8}}$ & 2.61 & 2.82 & 2.67 & $\mathbf{2 . 7 0}$ & $\mathbf{T}_{\mathbf{8}}$ & 3.07 & 3.09 & 3.14 & $\mathbf{3 . 1 0}$ & 2.90 \\
\hline & SEd & & $\mathbf{0 . 0 5 2}$ & & SEd & & $\mathbf{0 . 0 5 7}$ & $\mathbf{0 . 0 3 9}$ \\
\hline
\end{tabular}

Table.6 Effect of drip fertigation levels on non-reducing sugar (\%) of aonla cv. NA-7

\begin{tabular}{|c|c|c|c|c|c|c|c|c|c|c|}
\hline & \multicolumn{2}{|c|}{2012} & \multicolumn{7}{|c|}{2013} & \multicolumn{2}{c|}{ Pooled mean } \\
\hline Treatments & $\mathbf{R}_{\mathbf{1}}$ & $\mathbf{R}_{\mathbf{2}}$ & $\mathbf{R}_{\mathbf{3}}$ & Mean & Treatments & $\mathbf{R}_{\mathbf{1}}$ & $\mathbf{R}_{\mathbf{2}}$ & $\mathbf{R}_{\mathbf{3}}$ & Mean & 2012-2013 \\
\hline $\mathrm{T}_{\mathbf{1}}$ & 0.86 & 0.88 & 0.87 & $\mathbf{0 . 8 7}$ & $\mathbf{T}_{\mathbf{1}}$ & 0.96 & 0.91 & 0.98 & $\mathbf{0 . 9 5}$ & 0.91 \\
\hline $\mathrm{T}_{2}$ & 1.06 & 1.09 & 1.10 & $\mathbf{1 . 0 8}$ & $\mathbf{T}_{\mathbf{2}}$ & 1.13 & 1.15 & 1.08 & $\mathbf{1 . 1 2}$ & 1.10 \\
\hline $\mathrm{T}_{3}$ & 1.16 & 1.16 & 1.16 & $\mathbf{1 . 1 6}$ & $\mathbf{T}_{\mathbf{3}}$ & 1.23 & 1.19 & 1.18 & $\mathbf{1 . 2 0}$ & 1.18 \\
\hline $\mathrm{T}_{4}$ & 1.23 & 1.21 & 1.16 & $\mathbf{1 . 2 0}$ & $\mathbf{T}_{\mathbf{4}}$ & 1.49 & 1.37 & 1.40 & $\mathbf{1 . 4 2}$ & 1.31 \\
\hline $\mathrm{T}_{5}$ & 1.41 & 1.37 & 1.42 & $\mathbf{1 . 4 0}$ & $\mathbf{T}_{\mathbf{5}}$ & 1.64 & 1.64 & 1.64 & $\mathbf{1 . 6 4}$ & 1.52 \\
\hline $\mathrm{T}_{6}$ & 1.09 & 1.12 & 1.10 & $\mathbf{1 . 1 0}$ & $\mathbf{T}_{\mathbf{6}}$ & 1.14 & 1.16 & 1.21 & $\mathbf{1 . 1 7}$ & 1.13 \\
\hline $\mathrm{T}_{7}$ & 1.46 & 1.44 & 1.45 & $\mathbf{1 . 4 5}$ & $\mathbf{T}_{\mathbf{7}}$ & 1.68 & 1.61 & 1.71 & $\mathbf{1 . 6 7}$ & 1.56 \\
\hline $\mathrm{T}_{8}$ & 1.63 & 1.56 & 1.61 & $\mathbf{1 . 6 0}$ & $\mathbf{T}_{\mathbf{8}}$ & 1.83 & 1.86 & 1.87 & $\mathbf{1 . 8 5}$ & 1.72 \\
\hline & $\mathrm{SEd}$ & & $\mathbf{0 . 0 1 9}$ & & $\mathbf{S E d}$ & & $\mathbf{0 . 0 3 0}$ & $\mathbf{0 . 0 1 8}$ \\
\hline
\end{tabular}


Apart from higher sugar content observed with higher level of $\mathrm{K}$ applied, increased ascorbic acid content was noticed in fruits. This might be due to the fact that $\mathrm{K}$ could have helped to slow down the enzyme system that encouraged the oxidation of ascorbic acid, thus helping the plants to accumulate more ascorbic acid content in fruits (Ananthi, 2002). The present results are in agreement with that of Brantley and Warren (1960), Deswal and Patil (1984), Balakrishnan et al., (1996) and Mahalakshmi et al., (2000) in banana.

\section{Total sugars}

The total sugar content in the fruit was significantly different among the treatments and increased by application of 125 per cent RDF through fertigation $\left(\mathrm{T}_{8}\right)$ (4.30 and 4.95 $\%$ ) followed by 100 per cent RDF through fertigation $\left(\mathrm{T}_{7}\right)$ (3.95 and $4.47 \%$ ) during 2011-2012 to $2012-2013$ respectively. The lowest total sugar was recorded in control i.e. 2.27 and $2.45 \%\left(\mathrm{~T}_{1}\right)$ in $2011-2012$ to 2012 2013 respectively (Table 4).

Pooled mean values of total sugars were the highest in 125 per cent RDF through fertigation $\left(\mathrm{T}_{8}\right)(4.62 \%)$. It was followed by 100 per cent RDF through fertigation $\mathrm{T}_{7}$ $(4.20 \%)$. The lowest total sugar content was recorded by control $\left(\mathrm{T}_{1}\right)(2.36 \%)$. Post flowering application of $\mathrm{K}$ also favours the conversion of starch into simple sugars during ripening by activating 'sucrose synthase' enzyme, resulting in higher sugar content in fruits.

In plants, well supplied with $\mathrm{K}$, the osmotic potential of the phloem sap and the volume flow rate are higher than that observed in plants supplied with low available potassium level and as a result, sucrose concentration in the phloem sap is increased in well-nourished trees (Marschner, 1995).

\section{Reducing sugars}

The reducing sugar content in the fruit was significantly different among the treatments and increased by application of 125 per cent RDF through fertigation $\left(\mathrm{T}_{8}\right)$ (2.70 and 3.10 $\%)$. It was followed by 100 per cent RDF through fertigation $\left(\mathrm{T}_{7}\right)(2.50$ and $2.80 \%)$ during 2011-2012 to $2012-2013$, respectively. The lowest reducing sugar (1.40 and $1.50 \%)$ was recorded in control $\left(\mathrm{T}_{1}\right)$ in 2011-2012 to 2012-2013 respectively. The mean of reducing sugar content was the highest $(2.90 \%)$ in 125 per cent RDF fertigation treatment $\left(\mathrm{T}_{8}\right)$. It was followed by $\mathrm{T}_{7}$ (100 per cent RDF) through fertigation (2.64\%). The lowest reducing sugar was recorded by control $(1.45 \%)\left(\mathrm{T}_{1}\right)$ (Table 5$)$.

\section{Non-reducing sugars}

Among the two years taken for study, a significant effect was noticed during 20112012 to $2012-2013$ for the treatments applied with respect to non-reducing sugar content. The non-reducing sugar content in the fruit (1.60 and $1.85 \%$ ) was significantly increased by application of 125 per cent RDF through fertigation $\left(\mathrm{T}_{8}\right)$ (Table 6$)$. It was followed by 100 per cent RDF through fertigation (1.45 and $1.67 \%)\left(\mathrm{T}_{7}\right)$ during 2011-2012 to 2012 2013, respectively. The lowest non-reducing sugar $(0.87$ and $0.95 \%)$ was recorded in control $\left(\mathrm{T}_{1}\right)$ in 2011-2012 to $2012-2013$ respectively. The pooled mean of nonreducing sugar content was the highest (1.72 $\%$ ) in 125 per cent RDF fertigation treatment $\left(\mathrm{T}_{8}\right)$. It was followed by $\mathrm{T}_{7}$ through fertigation $(1.56 \%)$. The lowest non-reducing sugar was recorded by control (0.91 \%). Quality characters such as TSS, Ascorbic acid, Titrable Acidity, Reducing Sugar, Non Reducing Sugar and Total Sugar of the fruits were significantly enhanced due to application of 125 per cent RDF as WSF through drip in both the years of experimentation. 


\section{References}

Anonymous, 2011. Agriculture Statistics at a glance, Ministry of Agriculture Goverment of India.

Arun Shukla, K., D. Singh, and Anil Shukla, K. 2009. Performance of Indian gooseberry (Emblica officinalis) cultivars under arid region of India. Ind.J.Agr.Sci., 79 (11): pp. 849-852

Brantley, B.B. and G.F. Warren. 1960. Effect of nitrogen on flowering, fruiting and quality of the watermelon. Proc. of Amer. Soc. Hort. Sci., 75: 644-649.

Deswal, I.S. and V.K. Patil. 1984. Effects of $\mathrm{N}, \mathrm{P}$ and $\mathrm{K}$ on the fruit of watermelon. J. Maharashtra Agric. Univ., 9(3): 308309

Hanamanth, Y. A. 2002. Irrigation and fertilization studies in high density mango (Mangifera indica L.). M.Sc., Thesis submitted to Division of Horticulture, UAS, G.K.V.K, Bangalore

Lata, S. and R.P. Singh. 1993. Effect of nitrogen level and growth regulators on growth, yield and quality of chilli (Capsicum annuum L.) variety Pant C1. Veg. Sci., 20(1): 40-43

Mrinalini Raghava and J.P. Tiwari. 1998. Effect of boron on growth, quality and shelf-life of fruits of guava (Psidium guajava L.) cv. Sardar. Prog. Hort., 30(1-2): 68-72.

Opazo, D. and B. Razeto. 2001. Efecto de diferentes fertilizantes potásicos en elcontenido foliar de nutrientes, producción y calidad de fruta en naranjo cv. Valencia. Agricultura Técnica, 61:51-54.

Ram Kuamr, M.M., S.Syamal, V.Dwivedi, R.K.Anand and Vishwanath. 2011. Plant Archives, 11(2): pp.1053-1056.

Ruiz, R. 2000. Nutrición Mineral. In: Jorge Valenzuela (ed.), Uva de mesa en Chile. Instituto de Investigaciones Agropecuarias. pp. 113-143.

Ruiz, R. 2006. Effects of different potassium fertilizers on yield, fruit quality and nutritional status of Fairlane Nectarine trees and on soil fertility. Acta Hort., 721: $185-190$.

Singh, K. K., P. K. Singh, P. K. R. Pandey and K. N. Shukla. 2006. Integrated water and nutrient management of young mango crop in tarai region of Uttaranchal. In: $3^{\text {rd }}$ Asian Regional Conference, Sep. 10 - 16, PWTC, Kuala Lumpur. pp. 314

Thiyagarajan, T. 2006. Effect of micro sprinkler on growth, yield and nutrient dynamics pattern in groundnut. Ph.D (Engineering) Thesis, Tamil Nadu Agri. Univ., Coimbatore

Vijayakumar, R.M. 2001. Studies on influence of months of sowing and growth regulation on annual moringa (Moringa pterygosperma Gaertn.). Ph.D., thesis submitted to Tamil Nadu Agricultural University, Coimbatore

Virendra Singh, Prabhakar Singh and A. Kumar Singh. 2009. Pysico- chemical composition and evaluation of aonla cultivars under chhattisgarh conditions. Ind.J.Hort.66 (2). pp.267-270.

\section{How to cite this article:}

Suresh, P.M., S. Kumar, V. Swaminathan, A. Gurusamy and Shivakumar, T. 2018. Effect of Drip Fertigation Levels on Fruit Quality Characters of Aonla (Emblica officinalis Gaertn.) cv. NA-7. Int.J.Curr.Microbiol.App.Sci. 7(10): 2353-2359. doi: https://doi.org/10.20546/ijcmas.2018.710.272 